J. MED. MICROBIOL.-VOL. 18 (1984), 167-172

(C) 1984 The Pathological Society of Great Britain and Ireland

\title{
POLYMORPHONUCLEAR LEUKOCYTE CHEMOTAXIS BY MIXED ANAEROBIC AND AEROBIC BACTERIA
}

\author{
F. Namavar, A. M. J. J. Verweij-Van Vught, W. A. C. Vel, M. Bal and D. M. \\ MACLAREN
}

Research Group for Commensal Infections, Departments of Medical and Oral Microbiology, Schools of Medicine and Dentistry, Vrije Universiteit, Amsterdam, The Netherlands

SUMmaRY. The induction of chemotactic activity of polymorphonuclear leukocytes (PMNL) by anaerobic and aerobic bacteria alone or in combination was evaluated. Washed cells as well as the supernate of Proteus mirabilis were chemotactic for leukocytes. The supernate of cultures of two strains of Bacteroides fragilis contained small amounts of chemotactic factors. No chemotactic factors were released from the non-fragilis Bacteroides strains. The supernates of cultures of anaerobic bacteria were capable of inhibiting chemotaxis of leukocytes to the chemotactic factors of $P$. mirabilis. $P$. mirabilis and two strains of $B$. fragilis generated chemotactic factors in serum but none of the other Bacteroides spp. tested were able to induce serum chemotactic factors.

\section{INTRODUCTION}

The initial response of the body to invasion by pathogenic microorganisms and the events in the first few hours are critical in determining the outcome of infection. Neutrophil leukocytes play an important role in this early response because one of their functions is directed migration toward a specific location in the body, a phenomenon called chemotaxis. Chemotaxis follows the recognition by the neutrophil of chemical substances and ensures that leukocytes accumulate where they are needed. Subsequent phagocytosis forms a first line of defence. However, bacterial products have been shown to inhibit specific neutrophil functions such as phagocytosis and killing (Scharmann, Jacob and Portendörfer, 1976; Baehni et al., 1979). In previous investigations the presence of some but not all anaerobic bacteria inhibited the killing of aerobic bacteria (Namavar et al., 1983).

The purpose of this study was to determine whether the presence of anaerobic bacteria affected the chemotactic stimulus of an aerobic species because a negative influence on the attraction of neutrophils would increase the likelihood of infection becoming established. Chemotaxis may be induced by the release of substances from certain bacteria or by bacterial activation of serum chemotactic factors. We assessed both mechanisms by in-vitro experiments. 


\section{MATERIALS AND METHODS}

Bacteria. The following anaerobes were used: Bacteroides gingivalis strain W83, $B$. asaccharolyticus strain VPI 4199, B. loeschei strain ATCC 15930 (formerly B. melaninogenicus ss. melaninogenicus), B. fragilis strain 1503, and B. fragilis strain 5MB. The aerobic strain in all experiments was Proteus mirabilis strain P154. All bacteria used in this study were clinical isolates with the exception of $B$. asaccharolyticus strain VPI 4199, which was isolated from human faeces. Anaerobes were maintained by weekly subculture on $5 \%$ horse-blood-agar plates (Oxoid No. 2) supplemented with haemin $5 \mu \mathrm{g} / \mathrm{ml}$ (BDH) and menadione $2 \mu \mathrm{g} / \mathrm{ml}$ (Merck). $P$. mirabilis was maintained on Dorset egg slopes and subcultured before use on CLED-agar plates (Oxoid).

Preparation of supernates and cell suspensions. The broth normally used itself exerted a chemotactic influence on human PMNL. Therefore, to assess the chemotactic response of leukocytes towards bacteria, a medium was tested which had previously been described for measuring the chemiluminescence response of leukocytes (Namavar et al., 1983). This was a modification of a minimal medium for growth of $\boldsymbol{B}$. fragilis (Varel and Bryant, 1974). All the bacterial strains used grew sufficiently in this medium and it did not itself induce chemotaxis. Anaerobes were incubated for $48 \mathrm{~h}$ at $37^{\circ} \mathrm{C}$ in an anaerobic jar in an atmosphere of $\mathrm{N}_{2} 80 \%, \mathrm{H}_{2}$ $10 \%$ and $\mathrm{CO}_{2} 10 \%$. P. mirabilis was incubated overnight at $37^{\circ} \mathrm{C}$ in a shaking water bath. The numbers of anaerobic and aerobic bacteria were determined by optical density and adjusted to $1 \times 10^{9} \mathrm{cfu} / \mathrm{ml}$. Culture supernates were prepared by centrifugation $\left(1300 \mathrm{~g}, 15 \mathrm{~min}, 20^{\circ} \mathrm{C}\right)$ and filter sterilised through 0.45- $\mu \mathrm{m}$ membrane filters (Millipore Corp., Bedford, MA). Cells were washed twice in phosphate-buffered saline (PBS) and resuspended in modified minimal medium to give a concentration of $1 \times 10^{9} \mathrm{cfu} / \mathrm{ml}$. Both cells and supernates were tested for chemotactic factors.

Preparation of leukocytes. PMNL were separated from heparinised blood of healthy adults by dextran sedimentation. The leukocytes were washed once in TC medium 199 containing 2 mM L-glutamine and resuspended in the same medium at a concentration of $1 \times 10^{7}$ leukocytes $/ \mathrm{ml}$. The $p \mathrm{H}$ of the medium was adjusted to $7 \cdot 4$ with $7 \cdot 5 \% \mathrm{NaHCO}_{3}$ solution.

Induction of chemotactic factor in serum. Bacterial pellets were suspended in $1 \mathrm{ml}$ of pooled human serum diluted 1 in 2 in TC medium 199 and incubated at $37^{\circ} \mathrm{C}$ for $30 \mathrm{~min}$ in a shaking water bath to generate chemotactic factors in the serum. Bacteria were separated from the suspension by centrifugation $\left(1300 \mathrm{~g}, 15 \mathrm{~min}, 4^{\circ} \mathrm{C}\right)$. In some experiments activated serum was then incubated at $56^{\circ} \mathrm{C}$ for $30 \mathrm{~min}$.

Chemotactic assay. Agarose (Type 1: low EEO, Sigma) was dissolved in sterile distilled water at a concentration of $2.4 \%(\mathrm{w} / \mathrm{v})$ by heating for $30 \mathrm{~min}$ in a boiling water bath. After cooling in a $56^{\circ} \mathrm{C}$ water bath, the agarose was mixed with an equal volume of prewarmed $\left(56^{\circ} \mathrm{C}\right)$ buffer medium. This consisted of $20 \mathrm{ml}$ of TC medium $199(10 \times$ concentrated $), 2 \mathrm{ml}$ of $7 \cdot 5 \%$ sodium bicarbonate, $20 \mathrm{ml}$ of inactivated new-born calf serum (NBCS) and $58 \mathrm{ml}$ of sterile distilled water. A 10-ml volume of the agarose medium was delivered into each $60 \mathrm{~mm} \times 15 \mathrm{~mm}$ tissue-culture plate (No. 3002, Falcon, CA). Four series of three wells $3 \mathrm{~mm}$ in diameter and $3 \mathrm{~mm}$ apart were made in the agarose gel with a punch in a straight row (Nelson, Quie and Simmons, 1975). The plugs of agarose were removed and accumulated fluid soaked up with tissue paper. The centre well of each three-well series received $10 \mu \mathrm{l}$ of leukocyte suspension $\left(1 \times 10^{7} / \mathrm{ml}\right)$, the outer well $10 \mu \mathrm{l}$ of chemotactic factor and the inner well $10 \mu \mathrm{l}$ of control medium. The plates were incubated at $37^{\circ} \mathrm{C}$ in a humidified atmosphere containing $\mathrm{CO}_{2} 5 \%$ in air. After incubation for $3 \mathrm{~h}$, the plates were flooded with $5 \mathrm{ml}$ of methanol for $30 \mathrm{~min}$, then with $4 \%$ formalin for $30 \mathrm{~min}$. The agarose was removed and the cells stained with Wright's stain. Each migration figure was magnified 25 times under a microscope and chemotaxis was measured by subtracting the spontaneous migration from the directed migration. The chemotaxis of the supernate or the washed cells of $P$. mirabilis was considered to be $100 \%$.

Statistical analysis of the data was performed using analysis of variants and Student's t-test. 


\section{RESUlTS}

\section{Chemotactic factor of $P$. mirabilis}

Fig. 1 shows the mean chemotactic activity of the neutrophils from 10 different healthy donors when induced by the supernate and washed cells of $P$. mirabilis cultures. Both induced chemotaxis equally. Chemotactic factors produced by $P$. mirabilis were a property of viable cells; heat killed $\left(60 \mathrm{~min}, 70^{\circ} \mathrm{C}\right)$ and formalin killed $(0.5 \% \mathrm{v} / \mathrm{v})$ cells did not produce chemotactic factors. The heat-treated supernate did not show a significant difference in chemotactic stimulation from the unheated supernate. These results suggest that the chemotactic factors of $P$. mirabilis are extracellular and heat stable.
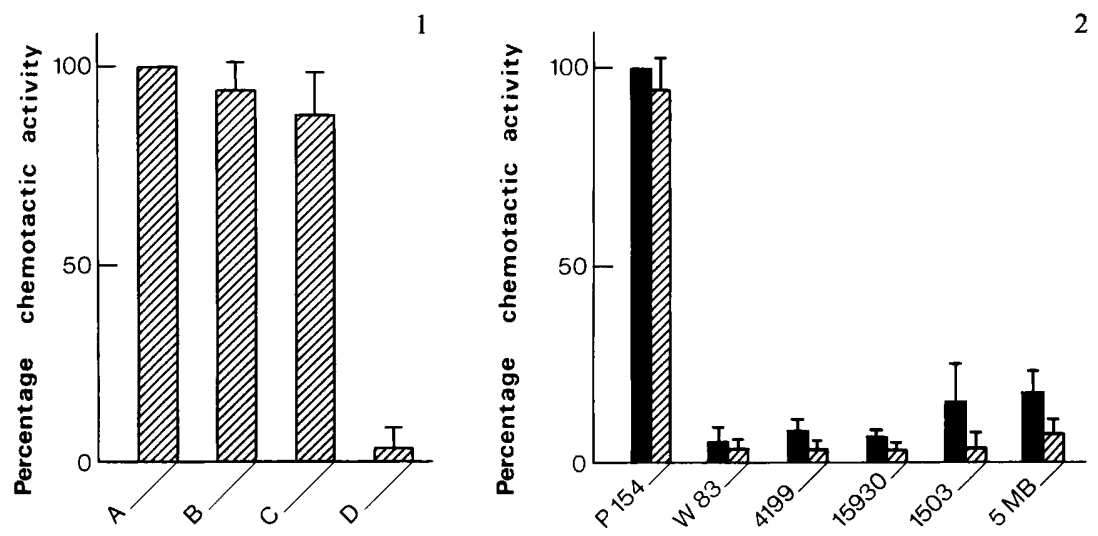

FIG. 1.-Chemotactic activities of PMNL induced by A) supernate, B) supernate heated for 30 min at $100^{\circ} \mathrm{C}$, C) viable cells, D) killed cells of $P$. mirabilis. Values are expressed as mean percentage \pm standard deviation of six experiments.

FIG. 2.-Chemotactic activities of PMNL induced by supernates ( $\square$ ) and washed cells (国) of Bacteroides spp. and $P$. mirabilis. Values are expressed as mean percentage \pm standard deviation of 10 experiments.

\section{Chemotactic factor of anaerobes}

The mean chemotactic activities of neutrophils when stimulated by the supernates and by the washed cells of Bacteroides spp. and $P$. mirabilis are compared in fig. 2 . The supernate and the washed cells of $P$. mirabilis produced far more powerful chemotactic factors than did those of Bacteroides spp. Neither the supernates nor the washed cells of the Bacteroides spp. tested produced potent chemotactic factors, although two strains of $B$. fragilis (1503 and 5MB) produced small amounts. Chemotactic stimulation by anaerobes was significantly lower than that by $P$. mirabilis $(P<0 \cdot 01)$.

\section{Induction of chemotaxis by combinations of anaerobes and P. mirabilis}

The effects of combining the supernates and the washed cells of $P$. mirabilis and Bacteroides spp. on the chemotactic activity of PMNL are shown in figs. 3 and 4 . The supernates of all Bacteroides spp. reduced significantly the chemotactic activity of PMNL towards $P$. mirabilis supernate (fig. 3) $(P<0 \cdot 05)$. No significant differences 
TABLE I

PMN leukocyte chemotactic activity generated in pooled human serum after incubation with anaerobic and aerobic bacteria

\begin{tabular}{l|cc}
\hline & \multicolumn{2}{|c}{ Percentage chemotactic activity* in } \\
\cline { 2 - 2 } $\begin{array}{l}\text { Activated } \\
\text { serum }\end{array}$ & $\begin{array}{c}\text { Activated serum } \\
\text { heated for 30 min at } 56^{\circ} \mathrm{C}\end{array}$ \\
\hline P. mirabilis P154 & 100 & $75 \pm 3 \cdot 5$ \\
B. gingivalis W83 & $14 \pm 2 \cdot 4$ & $12 \pm 3 \cdot 6$ \\
B. asaccharolyticus 4199 & $15 \pm 7 \cdot 0$ & $13 \pm 6 \cdot 8$ \\
B. loeschei 15930 & $10 \pm 2 \cdot 1$ & $10 \pm 1 \cdot 7$ \\
B. fragilis 1503 & $45 \pm 4 \cdot 5$ & $38 \pm 7 \cdot 0$ \\
B. fragilis 5MB & $55 \pm 7 \cdot 0$ & $45 \pm 3 \cdot 5$ \\
serum control & $13 \pm 2 \cdot 1$ & $10 \pm 3 \cdot 6$ \\
\hline
\end{tabular}

* Values are expressed as mean percentage \pm standard deviation of six experiments; activity with activated serum and $P$. mirabilis $=100 \%$.

were observed between anaerobes in inhibiting chemotactic stimulation by $P$. mirabilis. Using the same experimental procedures we found no significant differences when combinations of washed cells of $P$. mirabilis and Bacteroides spp. were compared with washed cells of $P$. mirabilis alone (fig. 4).

\section{Induction of chemotactic factors in serum by anaerobes and P. mirabilis}

The capacity of anaerobic and aerobic bacteria to generate chemotactic factors in serum is shown in table 1. P. mirabilis and two strains of $B$. fragilis (1503 and 5MB) generated chemotactic factors in serum. However, serum activated by these $B$. fragilis strains showed much less chemotactic activity than serum activated by $P$. mirabilis. None of the other Bacteroides spp. tested were capable of inducing serum chemotactic
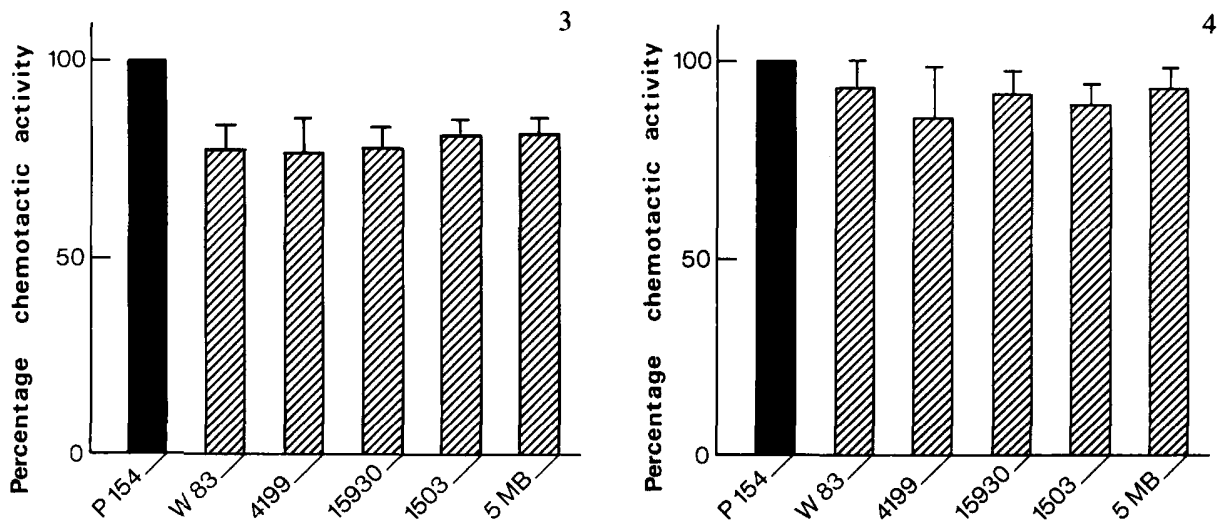

FIG. 3.-Chemotactic activities of PMNL induced by the supernate of $P$. mirabilis alone or in combination with supernates of Bacteroides spp. Supernate of $P$. mirabilis was diluted 1 in 2 in control medium (D) and supernates of Bacteroides spp. were diluted 1 in 2 in the supernate of $P$. mirabilis (四). Values are expressed as mean percentage \pm standard deviation of 10 experiments.

FIG. 4.-Chemotactic activities of PMNL induced by washed cells of $P$. mirabilis alone or in combination with washed cells of different Bacteroides spp. Washed cells of $P$. mirabilis were diluted 1 in 2 in control medium ( $\square$ ) and washed cells of Bacteroides spp. were diluted 1 in 2 in the washed cells of $P$. mirabilis (圆). Values are expressed as mean percentage \pm standard deviation of 10 experiments. 
factors. When serum-activated chemotactic factors induced by $P$. mirabilis and $B$. fragilis strains were heated for $30 \mathrm{~min}$ at $56^{\circ} \mathrm{C}$, the chemotactic activity of the serum was reduced but did not disappear.

\section{DisCUSSION}

Mixtures of anaerobic and aerobic bacteria are commonly implicated in various infections, e.g., post operative wound sepsis and pleuro-pulmonary infection (Gorbach and Bartlett, 1974; Mayrand and McBride, 1980). Animal studies have shown that the combination of anaerobes and aerobes produces sepsis which cannot be produced by the same doses of either component individually (Kelly, 1978; Onderdonk et al., 1979). Recent work has shown that anaerobic bacteria inhibit phagocytosis and killing of aerobic bacteria (Ingham et al., 1977 and 1981; Jones and Gemell, 1982; Namavar et al., 1983). This paper is the first report on the chemotactic activity of PMNL induced by mixed anaerobic and aerobic bacteria.

Cooked meat medium, trypticase soy broth and BM medium (van Steenbergen, Vlaanderen and De Graaff, 1981) used for growth of aerobes were themselves chemotactic to PMNL. Therefore, it was not possible to test the chemotactic stimulus of the supernates of anaerobes grown in these media. There are reports indicating that a wide variety of agents which are found in growth media are chemotactic, e.g., peptides (Showell et al., 1976), lectins (van Epps and Tung, 1977) and proteins, denaturated proteins and polypeptides (Wilkinson, 1974). The medium used in our experiments overcame this problem. Chemotactic factors of $P$. mirabilis were extracellular and heat stable. None of the Bacteroides spp. tested stimulated chemotaxis except the supernates of two strains of $B$. fragilis that did so moderately. This is in keeping with the reports of Adamu and Sperry (1981) that a slight to moderate amount of chemotaxis was induced by the supernate, the outer membrane and the lipopolysaccharide of $B$. fragilis. In contrast to our results, Sundqvist and Johansson (1980) reported that $B$. melaninogenicus and $B$. asaccharolyticus had a high capacity to induce chemotaxis by PMNL. On the other hand, Van Dyke et al. (1982) found that $B$. gingivalis and B. asaccharolyticus and some other obligate anaerobes did not produce chemotactic factors.

The supernates of anaerobes significantly inhibited chemotaxis of PMNL by $P$. mirabilis. Washed cells of anaerobic bacteria, in contrast to their supernates, had no effect on chemotactic attraction of $P$. mirabilis for PMNL. Interestingly, in a previous study (Namavar et al., 1983) we found that the supernates of some but not all anaerobes inhibited the killing of $P$. mirabilis by PMNL, whereas washed cells did not have such an effect. Of the anaerobes tested in the previous study, the supernate of a $B$. gingivalis strain showed the greatest inhibition. However, all anaerobes tested had equal effects on the inhibition of PMNL chemotaxis induced by $P$. mirabilis. The exact mechanism whereby the supernates of anaerobes interfere with the attraction of $P$. mirabilis for PMNL is not clear. It would seem that this is not a direct effect on PMNL, because their random migration is unaffected. Chemotactic factors generated in serum by $B$. fragilis strains were significantly less than those generated by $P$. mirabilis. Heating the serum activated by $P$. mirabilis or the two strains of $B$. fragilis slightly reduced the chemotactic effect of the serum. Wright and Gallin (1975) have shown that the fifth component of complement is stable at $56^{\circ} \mathrm{C}$ for $30 \mathrm{~min}$. In our 
study the heat-stable serum chemotactic activity may be a cleavage product of $\mathrm{C} 5$. This, however, has not been studied.

\section{REFERENCES}

Adamu S A, Sperry J F 1981 Polymorphonuclear neutrophil chemotaxis induced and inhibited by Bacteroides spp. Infection and Immunity 33:806-810.

Baehni P, Tsai C C, McArthur W P, Hammond B F, Taichman N S 1979 Interaction of inflammatory cells and oral microorganisms. VIII. Detection of leukotoxic activity of a plaque-derived gram-negative microorganism. Infection and Immunity 24:233-243.

Gorbach S L, Bartlett J G 1974 Anaerobic infections. New England Journal of Medicine 290:1177-1184, 1237-1245, 1289-1294.

Ingham H R, Sisson P R, Tharagonnet P, Selkon J B, Codd A A 1977 Inhibition of phagocytosis in vitro by obligate anaerobes. Lancet $2: 1252-1254$.

Ingham H R, Sisson P R, Middleton R L, Narang H K, Codd A A, Selkon J B 1981 Phagocytosis and killing of bacteria in aerobic and anaerobic conditions. Journal of Medical Microbiology 14:391-399.

Jones G R, Gemell C G 1982 Impairment by Bacteroides species of opsonisation and phagocytosis of enterobacteria. Journal of Medical Microbiology 15:351-361.

Kelly M J 1978 The quantitative and histological demonstration of pathogenic synergy between Escherichia coli and Bacteroides fragilis in Guinea-pig wounds. Journal of Medical Microbiology 11:513-523.

Mayrand D, McBride B C 1980 Ecological relationships of bacteria involved in a simple, mixed anaerobic infection. Infection and Immunity 27:44-50.

Namavar F, Verweij A M J J , Bal M, Van Steenbergen T J M, De Graaff J MacLaren D M 1983 Effect of anaerobic bacteria on killing of Proteus mirabilis by human polymorphonuclear leukocytes. Infection and Immunity 40:930-935.

Nelson R D, Quie P G, Simmons R L 1975 Chemotaxis under agarose: a new and simple method for measuring chemotaxis and spontaneous migration of human polymorphonuclear leukocytes and monocytes. Journal of Immunology 115:1650-1656.

Onderdonk A B, Louie T J, Tally F P, Bartlett J G 1979 Activity of metronidazole against Escherichia coli in experimental intra-abdominal sepsis. Journal of Antimicrobial Chemotherapy $5: 201-210$.

Scharmann W, Jacob F, Porstendörfer J 1976 The cytotoxic action of leucocidin from Pseudomonas aeruginosa on human polymorphonuclear leucocytes. Journal of General Microbiology 93:303-308.

Showell H J, Freer R J, Zigmond S H, Schiffmann E, Aswanikumar S, Corcoran B, Becker E L 1976 The structure-activity relations of synthetic peptides as chemotactic factors and inducers of lysosomal enzyme secretion for neutrophils. Journal of Experimental Medicine 143:1154-1169.

Sundqvist G, Johansson E 1980 Neutrophil chemotaxis induced by anaerobic bacteria isolated from necrotic dental pulps. Scandinavian Journal of Dental Research 88:113-121.

Van Dyke T E, Bartholomew E, Genco R J, Slots J, Levine M J 1982 Inhibition of neutrophil chemotaxis by soluble bacterial products. Journal of Periondontology 53:502-508

Van Epps D E, Tung S K 1977 Fucose-binding Lotus tetragonolobus lectin binds to human polymorphonuclear leukocytes and induces a chemotactic response. Journal of Immunology 119:1187-1189.

Van Steenbergen T J M, Vlaanderen C A, De Graaff J 1981 Confirmation of Bacteroides gingivalis as a species distinct from Bacteroides asaccharolyticus. International Journal of Systematic Bacteriology $31: 236-241$.

Varel V H, Bryant M P 1974 Nutritional features of Bacteroides fragilis subsp. fragilis. Applied Microbiology 18:251-257.

Wilkinson P C 1974 Chemotaxis and inflammation. Churchill Livingstone, London. p 54.

Wright D G, Gallin J I 1975 Modulation of the inflammatory response by products released from human polymorphonuclear leukocytes during phagocytosis. Generation and inactivation of the chemotactic factor C5a. Inflammation 1:23-39. 